Article

\title{
Water-Energy-Food Nexus Framework for Promoting Regional Integration in Central Asia
}

\author{
Olimjon Saidmamatov ${ }^{1}$ (D), Inna Rudenko ${ }^{1}$, Stephan Pfister ${ }^{2, *}$ and Jacek Koziel ${ }^{3}$ (D) \\ 1 Faculty of Tourism and Economics, Urgench State University, Urgench 220100, Uzbekistan; \\ saidolimjon@gmail.com (O.S.); irudenko@mail.ru (I.R.) \\ 2 Ecological Systems Design, Swiss Federal Institute of Technology, 8093 Zurich, Switzerland \\ 3 Department of Agricultural and Biosystems Engineering, Owa State University, Ames, IA 5001, USA; \\ koziel@iastate.edu \\ * Correspondence: stephan.pfister@ifu.baug.ethz.ch
}

Received: 3 June 2020; Accepted: 29 June 2020; Published: 3 July 2020

\begin{abstract}
This paper focuses on regional integration through the lenses of the Water-Food-Energy (WEF) nexus, a concept putting strong emphasis on cross-sectoral and multi-level interactions as well as on resource interdependencies. There is an extensive amount of published research focusing on the Aral Sea basin. In this paper, the authors build upon these different contributions and provide a meta-analysis of the literature of WEF nexus opportunities in Central Asia (CA) countries. This paper contributes to ongoing discussions regarding how the WEF Nexus can represent an opportunity for reinforced collaboration regarding resources management. To do so, focusing on existing literature, this paper first (1) explores how the nexus can be a relevant instrument for regional integration. Second (2), it provides an overview of water, food, energy conditions and challenges in the Aral Sea basin in particular. Third (3), synthesizing existing research, the authors identify critical variables to be considered as hurdles or leverage points for WEF nexus implementation in the Aral Sea basin. Finally (4), we go back to our initial set of questions and identify some possible avenues for future research.
\end{abstract}

Keywords: water-energy-food nexus; Aral Sea; water resource management; regional integration; Central Asia

\section{Introduction}

Central Asia (CA) is a young integrated region after the collapse of Soviet Union in the 1990s. Its population is over 70 million, while having rich mineral resources to cover energy demand. Uzbekistan and Kazakhstan have long-lasting coal, oil resources that are now used for electricity generation intensively. Most of the energy infrastructure has been established during the Soviet period [1]. It is appropriate to say that the traditional energy system faces huge inefficiency and technical losses due to the old infrastructure established in the 1960s.

To overcome the losses and inefficiency, CA economies are considering finding sustainable energy solutions. In upstream countries, such as Tajikistan and Kyrgyzstan, water is a key supplier of energy, while it is important for downstream countries as a source of agriculture [2]. Thus, water plays an important role in the provision of energy solutions in Central Asia.

Back in the 1960s, the Soviet Union decided to transform the Karakum and Kyzylkum deserts of Central Asia into cotton plantations via directing the flow of Amudarya and Syrdarya rivers that were flowing into the Aral Sea, which was the 4th largest lake in the world [3]. This decision resulted in a 
significant human-made mistake that led the Aral Sea drying out completely. Logically, cotton plantations do not occur in the desert area regardless of how much water one feeds in.

Iconic images of the dried Aral Sea show particularly well the environmental tragedy that the region suffers for the last decades [4]. Mainly fed by the Amu Darya and Syr Darya rivers, the sea levels declined massively since the sixties along with the diverting of these rivers to supply irrigation schemes and to boost agricultural production (mainly cotton) in the Karakum and Kyzylkym deserts [5]. These massive environmental changes in the region result from the misplaced policies that were undertaken between the sixties and the nineties.

On the one hand, during Soviet time, the management of natural resources depended on a planned strategy led at the Soviet Union level called the "Aral Sea Plan", a massive irrigation scheme aiming to transform the region into an agricultural belt focusing on cotton production. The objective was to double the agricultural production capacities of the region [6]. This irrigation scheme was supported by the two rivers (Amu Darya and Syr Darya) and benefited from strong upstream-downstream coordination including shared energy production capacities. At that time, the system was depending on complementarities among countries with Tajikistan and Kyrgyzstan ensuring the supply of water and the other countries focusing on irrigation and hydrocarbon production [7-9].

On the other hand, the collapse of the Soviet Union in the early nineties and the independence of the five countries in the region (Kazakhstan, Kyrgyzstan, Tajikistan, Turkmenistan and Uzbekistan) deeply modified the collaboration schemes and dismantled the regional integration of Central Asia. In fact, uncoordinated competition among the five countries and the will of the new independent countries to reach self-sufficiency, energy and food security increased water intakes and, consecutively, led to the drying of the Aral Sea. For instance, $90 \%$ of the Aral Sea basin water flows are currently withdrawn for irrigation purposes [10].

Considering this context of strong interdependences between the basin's countries regarding the functioning of irrigation schemes in semi-arid areas and food and energy security, the stakes are particularly high [11]. This fact is reinforced by climate changes in the region that exacerbate an already difficult situation and become an important source for international tensions [12]. Such context implies an increase of complexity in a region characterized by already difficult trade-offs for resource allocation and for the provision of arbitrations by countries that are not at ways sufficiently equipped with financial and institutional capacities to deal with such challenges.

Regional integration and collaboration is needed urgently to promote a more efficient use of water for energy and food production and to address environmental problems related to the overuse of water resources [3]. The challenge here is to rebuild an efficient and sustainable regional integration in the framework of diverging national interests and long-standing political tensions, including a lack of upstream-downstream coordination.

In this regard, this chapter focuses on such regional integration through the lenses of the Water-Food-Energy (WEF) nexus [1], a concept putting strong emphasis on cross-sectoral and multi-level interactions as well as on resource interdependencies [13]. An extensive amount of published research focuses on the Aral Sea basin. In this paper, the authors build upon these different contributions and provide a meta-analysis of the literature of WEF nexus opportunities in CA countries. As other authors, we underline the synergy opportunities of the WEF nexus conceptual framework to identify possible benefit-sharing mechanisms, to ensure equitable resources management across diverse institutional levels and sectors of activity in a transboundary setting [14,15]. This is particularly the case in a region where resource endowments vary widely among the different countries [16].

We therefore ask the following set of research questions: (i) What are the key dimensions of the WEF Nexus that are considered as critical by the literature? (ii) To what extent a water-energy-nexus-based conceptual framework may be used as an entry point for reinforced collaboration and regional integration? 
(iii) What would be the key elements needed to operationalize the proposed water-energy nexus framework in the Aral Sea basin?

This paper contributes to ongoing discussions [2-4] regarding how the WEF Nexus can represent an opportunity for reinforced collaboration regarding resources management. To do so, focusing on existing literature, this paper first (1) explores how the WEF nexus can be a relevant instrument for transboundary collaboration. Second (2), it provides an overview of water, food, energy conditions and challenges in the Aral Sea basin in particular. Third (3), synthesizing existing research, authors identify critical variables to be considered as hurdles or leverage points for WEF nexus implementation in the Aral Sea basin. Finally (4), we go back to our initial set of questions and identify some possible avenues for future research.

\section{Added Values of the WEF Nexus Approach for Transboundary Collaboration}

WEF nexus narratives [1,17] are articulated around the idea that described challenges of water, energy and food security in complex institutional and environmental settings require new ways of thinking and flexible forms of governance [18] as well as innovation in all policy dimensions. In this regard, sustainable access to and management of resources is a necessary condition for long-term economic growth and development [19]. Understanding complex intersectoral and multiscalar linkages and improving nexus efficiency could mean a major win-win outcome for the wellbeing of a concerned population [20]. As a matter of fact, as underlined by different authors $[18,21]$, the WEF nexus approach gained traction in the past few years. As an illustration, we can observe only seven papers on Google Scholar search for "water energy food nexus" in 2011 while the quantity of papers reached 3350 occurrences in 2019. Two reasons can be considered as key drivers for an increased scientific attention on the WEF Nexus globally [22]. Firstly, the global community has rising perception on the economic risks of the nexus. Secondly, science is using the nexus as a new structure for international policy debate about the connection between resource usage and sustainable development. The WEF nexus approach can be a relevant instrument for transboundary contexts in particular [9]. It can indeed generate new approaches to intersectoral and multi-level collaborations and open the discussion towards new pathways of collaboration among involved countries, considering a broader framing of stakes at play and of existing causal relationships and trade-offs. The authors [23] underline that WEF nexus dimensions are strongly context specific. In the case of Central Asia, one can observe strong inequalities regarding resource allocation and a natural division of labor between upstream and downstream countries leaving room for reinforced regional integration. For instance, the management of critical infrastructures such as dams can, if no coordination takes place, have knock on effects on food and energy security. Coordination is key and the WEF nexus framework has the potential to complement existing approaches for the management of transboundary river basins [22].

A core issue of the water-energy-food nexus is the trade-off between water-dependent activities. Accordingly [23], the current nexus situation in the ASB (Aral Sea basin) is a high-profile example of the increasing human water use and diminishing environmental water. Reduced lake areas, increased salinity, a loss of fish species, desertification, dust storms, and climate change along the shoreline are all consequences of irrigation expansion and reduced inflows. The ecological change brought the collapse of the fishing industry, high unemployment, the loss of irrigated land to salinization, poorer diets and health problems [6].

Aral Sea basin countries annually consume $116 \mathrm{~km}^{3}$ of water, where $78 \mathrm{~km}^{3}$ originates from Amu Darya (Table 1) which is twice as large as the contribution of Syr Darya $\left(37 \mathrm{~km}^{3}\right)$. Respectfully, $70 \%$ of Amu Darya and Syr Darya originate in the mountains of Tajikistan and Kyrgyzstan [24]. 
Table 1. Country areas in the Aral Sea basin [10].

\begin{tabular}{|c|c|c|c|c|c|c|}
\hline \multirow{2}{*}{ Basin } & \multicolumn{2}{|r|}{ Area } & \multirow{2}{*}{ Countries } & \multirow{2}{*}{$\begin{array}{c}\text { Area of Country } \\
\text { in Basin }\left(\mathbf{k m}^{2}\right)\end{array}$} & \multirow{2}{*}{$\begin{array}{l}\text { As of Total Area } \\
\text { of the Basin }\end{array}$} & \multirow{2}{*}{$\begin{array}{l}\text { As of } \% \text { of Total } \\
\text { Area of the Country }\end{array}$} \\
\hline & $\mathrm{km}^{2}$ & $\%$ of Central Asia & & & & \\
\hline \multirow{4}{*}{ Syr Darya } & \multirow{4}{*}{531,650} & \multirow{4}{*}{$11 \%$} & Kazakhstan & 345,000 & 64.9 & 12.7 \\
\hline & & & Kyrgyzstan & 110,570 & 20.8 & 55.3 \\
\hline & & & Tajikistan & 15,680 & 2.9 & 11 \\
\hline & & & Uzbekistan & 60,400 & 11.4 & 13.5 \\
\hline \multirow{5}{*}{ Amu Darya } & \multirow{5}{*}{$1,023,610$} & \multirow{5}{*}{$22 \%$} & Afghanistan & 166,000 & 16.2 & 25.4 \\
\hline & & & Kyrgyzstan & 7800 & 0.8 & 3.9 \\
\hline & & & Tajikistan & 125,450 & 12.3 & 88.0 \\
\hline & & & Turkmenistan & 359,730 & 35.1 & 73.7 \\
\hline & & & Uzbekistan & 364,630 & 35.6 & 81.5 \\
\hline \multirow{2}{*}{ Tedzhen-Murghab } & \multirow{2}{*}{182,010} & \multirow{2}{*}{$4 \%$} & Afghanistan & 80,000 & 44 & 12.3 \\
\hline & & & Turkmenistan & 102,010 & 56 & 20.9 \\
\hline \multirow{6}{*}{ Aral Sea basin } & \multirow{6}{*}{$1,737,270$} & \multirow{6}{*}{$37 \%$} & Afghanistan & 246,000 & 14.2 & 37.7 \\
\hline & & & Kazakhstan & 345,000 & 19.9 & 12.7 \\
\hline & & & Kyrgyzstan & 118,370 & 6.8 & 59.2 \\
\hline & & & Tajikistan & 141,130 & 8.1 & 99.0 \\
\hline & & & Turkmenistan & 461,740 & 26.6 & 94.6 \\
\hline & & & Uzbekistan & 425,030 & 24.5 & 95 \\
\hline
\end{tabular}

Considering water consumption in the region (Figure 1), Uzbekistan is the biggest water consumer $\left(56 \mathrm{~km}^{3}\right)$ in the region, while the water usage per capita is the highest in Turkmenistan ( $5952 \mathrm{~m}^{3} /$ year) whereas agriculture remains still the dominant consuming sector in Central Asia [25].

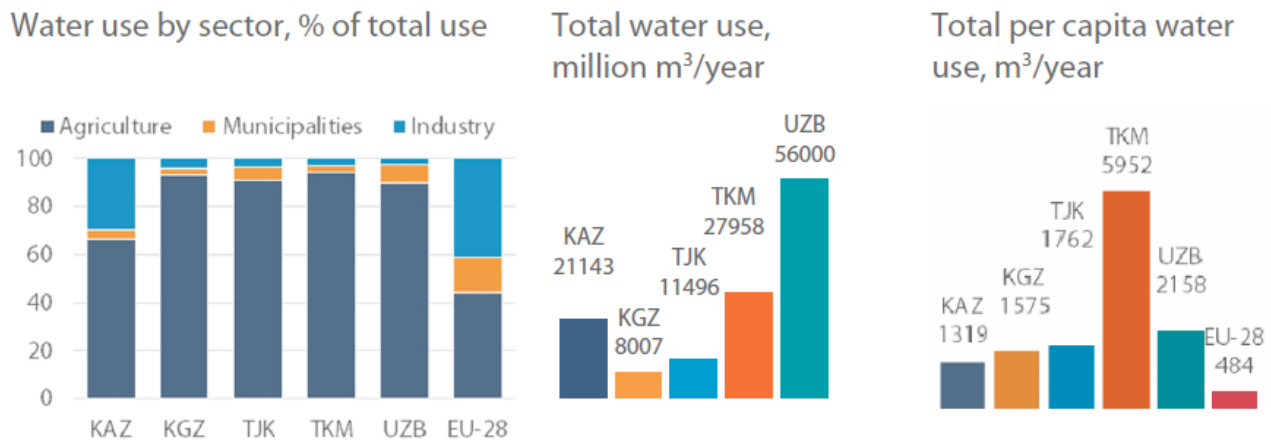

Central Asian countries use most of their water for irrigation, and therefore have very high total water consumption. Uzbekistan and Turkmenistan are the biggest users.

Figure 1. Water use in Central Asian countries and the EU [25].

The region is well known for its extreme continental climate, reaching up to $49.8^{\circ} \mathrm{C}$ in summertime, where water evaporation amounts to $1700 \mathrm{~mm} / \mathrm{y}$ [26]. Interconnections among agriculture, energy and water are important to understand when they are explained in monetary values.

Table 2 shows the pivotal role played by Tajikistan and Kyrgyzstan in Central Asia regarding hydropower production with, at the same time, minimal electricity and water consumption per capita. On their turn, downstream countries Uzbekistan and Turkmenistan have the highest agriculture potential leading to consuming most of the water from Amu Darya. 
Table 2. Key water-energy-food parameters in the Aral Sea basin [27].

\begin{tabular}{cccccc}
\hline Country & $\begin{array}{c}\text { GDP (USD } \\
\text { Billion), 2017 }\end{array}$ & $\begin{array}{c}\text { Agriculture Value } \\
\text { Added to GDP, 2015 }\end{array}$ & $\begin{array}{c}\text { Annual Water Use } \\
\text { (Million } \mathbf{~ m}^{\mathbf{3}} \text { Year) }\end{array}$ & $\begin{array}{c}\text { Electric Power Consumption } \\
\text { (kWh Per Capita), 2014 }\end{array}$ & $\begin{array}{c}\text { Electricity Production from } \\
\text { Hydroelectric Sources (\% of Total), 2015 }\end{array}$ \\
\hline Kazakhstan & 162.8 & $4.7 \%$ & 21,143 & 5600 & 8.7 \\
Kyrgyz & 7.5 & $14.1 \%$ & 8007 & 1941 & 85.2 \\
Republic & 7.1 & $21.9 \%$ & 11,496 & 1480 & 98.5 \\
Tajikistan & 37.9 & $9.3 \%$ & 27,958 & 2679 & 0.0 \\
Turkmenistan & 49.6 & $16.7 \%$ & 56,000 & 1645 & 20.7 \\
Uzbekistan & & & & \\
\hline
\end{tabular}

\section{The Situation in Amu Darya River Basin}

Since agriculture and fossil fuel export are key indicators of Uzbekistan and Turkmenistan, it leads to the perception that the more the country consumes water, the smaller the tendency to generate electricity from hydro resources. However, small/mini hydro plants are possible to install to cover the energy needs in a decentralized way. On its turn, it leads to economizing the fossil fuel of downstream countries. However, only a $4.7 \%$-small fraction of Kazakhstan's GDP is generated in the agriculture sector while Uzbekistan's parameter is $16.7 \%$.

It is noteworthy that more than half of the region's Gross Domestic Product (GDP) directly comes from agriculture, which also employs $40 \%$ of its labor [11]. The main reason behind high-water consumption in Uzbekistan and Turkmenistan is related to high irrigation practices, mainly for cotton (Table 3). From the point of yield, the highest cotton productivity belongs to Uzbekistan ( 2.3 ton/ha) and Turkmenistan (2.2 ton/ha) with proportional high-water consumption ( $14 \mathrm{~m}^{3} /$ ha/year). Dependence on agriculture is the lowest in Tajikistan (0.5 mln ha) and Afghanistan (0.4 mln ha).

Table 3. Agricultural data by country and crop [28].

\begin{tabular}{|c|c|c|c|c|c|}
\hline Country & Crop & $\begin{array}{c}\text { Yield } \\
\text { (tons/Ha) }\end{array}$ & $\begin{array}{c}\text { Cost } \\
\text { (\$US/Ha) }\end{array}$ & $\begin{array}{l}\text { Water Requirements } \\
\left(\mathrm{m}^{3} / \mathrm{ha} / \text { Year }\right)\end{array}$ & $\begin{array}{l}\text { Total Land Area in Production within } \\
\text { the Amu Darya Basin (Million Ha) }\end{array}$ \\
\hline \multirow{3}{*}{ Tajikistan } & cotton & 1.8 & 444 & 12 & \multirow{3}{*}{0.5} \\
\hline & wheat & 1.5 & 168 & 8 & \\
\hline & vegetable & 12 & 500 & 12 & \\
\hline \multirow{3}{*}{ Afghanistan } & cotton & 1.8 & 444 & 12 & \multirow{3}{*}{0.4} \\
\hline & wheat & 1.6 & 165 & 8 & \\
\hline & potato & 12 & 503 & 12 & \\
\hline \multirow{3}{*}{ Uzbekistan } & cotton & 2.3 & 390 & 14 & \multirow{3}{*}{2.3} \\
\hline & wheat & 1.5 & 283 & 6 & \\
\hline & vegetable & 11 & 702 & 11 & \\
\hline \multirow{3}{*}{ Turkmenistan } & cotton & 2.2 & 392 & 14 & \multirow{3}{*}{1.1} \\
\hline & wheat & 1.5 & 283 & 6 & \\
\hline & vegetable & 11 & 702 & 11 & \\
\hline
\end{tabular}

Melting of the snow originates from the water volume of the Amu Darya where the largest supply of water is observed during summer making it accessible for irrigation purposes. When the water reaches Nukus (Uzbekistan) via the deserts of Turkmenistan, $7 \mathrm{~km}^{3}$ of water gets evaporated. In general, the basin consumes $78.46 \mathrm{~km}^{3}$ of water annually (Table 4) [10].

Water withdrawal in the basin increased to $107 \mathrm{~km}^{3}$ in 2006 and most of the water $\left(96 \mathrm{~km}^{3}\right)$ was spent for irrigation purposes [29]. Uzbekistan and Turkmenistan are dominant users of the Amu Darya. The alarming point is that the ASB has very high water withdrawal per irrigated hectare-up to $14,000 \mathrm{~m}^{3} / \mathrm{ha}$, which is a consequence of inefficient water management in dry areas [28]. 
Table 4. Mean annual runoff in the Aral Sea basin ( $\mathrm{km}^{3} /$ year) [10].

\begin{tabular}{cccccc}
\hline \multirow{2}{*}{ Country } & \multicolumn{3}{c}{ River Basin } & \multicolumn{2}{c}{ Total Aral Sea Basin } \\
\cline { 2 - 6 } & Syr Darya & Amu Darya & Tedzhen-Murghab & $\mathbf{~ k m}^{\mathbf{3}}$ & $\%$ \\
\hline Kazakhstan & 3.3 & & & 3.3 & 2.8 \\
Kyrgyzstan & 27.42 & 1.93 & & 29.35 & 24.8 \\
Tajikistan & 1.01 & 59.45 & 0.3 & 60.46 & 51 \\
Turkmenistan & & 0.68 & & 0.98 & 0.8 \\
Uzbekistan & 4.84 & 4.7 & 3.1 & 14.5 & 8.1 \\
Afghanistan & & 11.7 & 3.4 & 118.43 & 12.5 \\
Aral Sea basin & 36.57 & 78.46 & & & 100 \\
\hline
\end{tabular}

The performance indicators of the irrigation depend on the conveying canals as well. For example, Niyazov canal in Turkmenistan, the world's longest irrigation canal, can deliver up to $20 \mathrm{~km}^{3}$ of water from Amu Darya to the western part of Turkmenistan. This canal is one of the key reasons behind the inefficient discharge of water from the Amu Darya as high water evaporation is observed in the delivery process over $1375 \mathrm{~km}$ in the Karakum desert [10]. This canal was constructed in the 1950s and its inlet to Amu Darya is located at the border of Turkmenistan and Uzbekistan. Karakum canal is an integrated water resource management system consisting of Amu Darya, Murghab and Tedzhen rivers heading to Ashgabat for irrigation (1.2 million ha) and consumption purposes [30].

Current challenges will likely be aggravated by emerging problems-in particular, climate change. The Central Asian region is warming faster than the global average, and climate change will hit the region sooner and harder [31]. In addition, it is calculated that 7.5 million Uzbeks, 4.8 million Tajiks, 2 million Kyrgyz and 1.5 million Turkmens lack access to safe drinking water [32].

\section{Managing Challenges and Leveraging Opportunities: Integrating WEF Nexus Elements}

The management of transboundary water resources during the Soviet Union reveals the existence of a benefit-sharing mechanism. On the other hand, water was stored upstream until release for irrigation downstream during the summer period; on the other hand, fossil fuels were traded upstream during the winter period. Surplus hydropower was released to the Central Asian Power System. To some extent, a normative regulation and institutional guidelines were in place through imposition by the Soviet Union [33]. From an institutional point of view, the Soviet Union was instrumental to supervise and frame transboundary water resources management and to define a system where the release of water was negotiated and defined following interests of both upstream and downstream countries.

However, the unilateral development approach dominated over the communism principles with the breakdown of regional cooperation in the 1990s [3]. This reason persuades authors to think that a high level of securitization in the region is considered an obstacle against synergizing WEF nexus opportunities in the region. Another approach can be improving livelihoods through market mechanisms with a sustainable supply of water, energy and agriculture.

So far, many aims of nexus approaches have encountered significant barriers to progress, including challenges to cross-disciplinary collaboration, complexity, the political economy and the incompatibility of current institutional structures [21]. Due to these interdependencies, local authorities cannot fully cover synergies and trade-offs of the WEF nexus in long- and short-term periods [34]. Since the Amu Darya is a main contributor to the Aral Sea basin, today it shows real evidence for WEF tensions in the region. The history of the situation goes back to the Soviet period where all decisions were centrally made from Moscow, leading to irrational decisions on sharing water both for hydropower and agriculture purposes [35]. 
The benefit-sharing theory in transboundary water resources management and development explain that countries establish partnership if the net advantage of collaboration is higher than the net advantage of non-collaboration [36]. To make a holistic evaluation of hurdles and cooperation opportunities, SWOT analysis is conducted (Table 5) to provide the real scenario of influencing internal and external factors. From a strategic point of view, SWOT (strength, weakness, opportunity, threats) analysis for the nexus helps to identify priorities for nationalization or integration in Central Asia. Positive and negative sides of nexus integration form the strategic position of ASB countries in the global arena.

Table 5. Strength, weakness, opportunity, threats (SWOT) analysis for Water-Food-Energy (WEF) integration in Central Asia water management.

\begin{tabular}{|c|c|c|c|}
\hline \multicolumn{3}{|c|}{ Strengths } & Weaknesses \\
\hline 1 & $\begin{array}{c}\text { maximzing net benefit sharing among CA } \\
\text { countries [36] }\end{array}$ & 1 & $\begin{array}{l}\text { Upstream countries export less hydro } \\
\text { energy that might lead to decrease in } \\
\text { revenue generated [2] }\end{array}$ \\
\hline 2 & $\begin{array}{l}\text { decreasing deficit of agriculture in TAJ and } \\
\text { KYR [37] }\end{array}$ & 2 & $\begin{array}{c}\text { shortage of water/energy in upstream } \\
\text { when it is released to downstream in } \\
\text { spring/summer [10] }\end{array}$ \\
\hline 3 & $\begin{array}{l}\text { decreasing deficit of water and energy in } \\
\text { KAZ, UZB, TKM [10] }\end{array}$ & 3 & $\begin{array}{l}\text { downstream countries cannot export fossil } \\
\text { fuel to China/Russia when natural } \\
\text { resources are shared in between CA } \\
\text { countries [14] }\end{array}$ \\
\hline 4 & $\begin{array}{l}\text { sustainable and equal sharing of } \\
\text { transboundary resources [22] }\end{array}$ & 4 & $\begin{array}{l}\text { Upstream cannot supply hydropower for } \\
\text { its heating during the winter period [38] }\end{array}$ \\
\hline 5 & $\begin{array}{l}\text { promoting economic growth, strengthen } \\
\text { social ties, political integration, } \\
\text { demographic development [3] }\end{array}$ & 5 & $\begin{array}{l}\text { Downstream countries would need to sell } \\
\text { fossil fuel to upstream countries at } \\
\text { discounted prices for heating purposes in } \\
\text { the winter period }[35,39]\end{array}$ \\
\hline & Opportunity & & Threats \\
\hline 1 & $\begin{array}{l}\text { the maximizing economic benefit of } \\
\text { transboundary natural resources [36] }\end{array}$ & 1 & $\begin{array}{l}\text { Weakening political/economic ties with key } \\
\text { partner countries: China, Russia, United } \\
\text { States [29] }\end{array}$ \\
\hline 2 & $\begin{array}{c}\text { Opportunity to mitigate negative } \\
\text { consequences of climate change in ASB [12] }\end{array}$ & 2 & $\begin{array}{l}\text { Change in political relations with far } \\
\text { neighbors in the Caspian Sea basin, Far } \\
\text { East, Balkans }[14,40]\end{array}$ \\
\hline 3 & $\begin{array}{c}\text { Strong political, economic, social, } \\
\text { demographic, technological integration in } \\
\text { Central Asia [3] }\end{array}$ & 3 & $\begin{array}{c}\text { Nationalism policies of each CA countries } \\
\text { weaken after regional integration [41] }\end{array}$ \\
\hline 4 & $\begin{array}{l}\text { A single unified network of sharing water } \\
\text { and energy resources as it was in the Soviet } \\
\text { Union [33] }\end{array}$ & 4 & $\begin{array}{l}\text { Change in export/import, trade balance, } \\
\text { public debt, currency } \\
\text { appreciation/depreciation of each CA } \\
\text { country [42] }\end{array}$ \\
\hline 5 & $\begin{array}{c}\text { Integrated CA can help to solve the } \\
\text { political/economic problems in } \\
\text { Afghanistan [39] }\end{array}$ & 5 & $\begin{array}{c}\text { High resource interdependence among CA } \\
\text { countries leads to less political will to } \\
\text { cooperate with eastern and western } \\
\text { neighbors [6] }\end{array}$ \\
\hline
\end{tabular}

Slow industrial and agricultural reforms, an absence of regional cooperation, and poor institutional development led to a crisis in the WEF nexus [4]. In spite of political disconnection in Central Asia, regional dynamics are further problematic influenced by the global political economy. If we analyze 
from a neutral perspective, there is no shortage of water and energy resources in Central Asia. All of the WEF-nexus-related challenges are the result of poor market structure, diplomacy and governance in the region [14]. Regardless of having a strong resource reserve, most of the CA countries are still listed among the least developing countries.

Considering that upstream countries (Tajikistan, Kyrgyzstan) are rich in water and energy resources and downstream countries (Kazakhstan, Uzbekistan) have economies of scale on agriculture, each community calculates the benefits of acting alone compared to the benefits of various cooperation strategies in the transboundary basin $[3,43]$. One of the most pressing challenges is to organize the political and administrative cooperation among CA countries to finance the large-scale investments to alter the allocation of water in the basin among locations, sectors and crops [16].

If the energy production is maximized at Rogun and Dastijum Reservoirs, the economic benefits to all four countries could increase in supporting irrigated agriculture for both normal and drought conditions. In general, two dams can increase the water volume from autumn until spring, making the water mischarge available for summer irrigation in downstream countries [16]. However, upstream countries have interest to use this water discharge for hydropower purposes when the electricity production is maximized. This conflict of interests requires careful and conscious political negotiations among CA stakeholders on the working environment [16]. If the upstream countries are jealous of water, they are able to generate the electricity at the expense of irrigation of downstream economies leading to again growing conflict when food shortage occurs in the region.

Another associated problem is the poor entrustment and loyalty in the region. Mainly, the absence of data exchange prevented the initiation of a hydro-meteorological system that could guarantee rational resource allocation in the region. Whilst other platforms are working for data exchange, reliable information about the environment and, in particular, water resources is not currently available in a consolidated and credible platform [35].

The irrigation networks of Central Asia were largely built between 1950s-80s without any significant upgrading in the last years. It is hard to believe that half of the water is lost before reaching the final destination due to worsening irrigation networks and an increasing evaporation rate [44].

Tajikistan can strengthen its energy potential via cutting the irrigation sector of downstream neighbors. Uzbekistan and Turkmenistan demand water for agriculture mostly in summer, but Tajikistan has an interest in releasing water in winter [45]. In this case, Uzbekistan and Turkmenistan would need to sacrifice cotton plantations [46] where most of the population is employed [47].

\section{Conclusions: From Conflict to Cooperation}

This paper conducted meta-analysis with the perspective of bringing more water to the final destination-the Aral Sea-and synergizing the water-energy-food nexus among CA countries as a solution to mitigate the negative consequences of climate change, environmental catastrophe in Central Asia and even globally. In order to bring more water reachable to the Aral Sea towards mitigating climate change in the basin, the following suggestions can be derived:

a. Synergizing the water-energy-food nexus is urgently needed to foster cooperation among CA countries and lead to effective resource management in the region.

b. The qualitative performance of inter-governmental organizations can be an essential element for supervision and guidance of the neighboring CA countries in distributing water, energy and food of respecting countries.

c. The energy focus of upstream countries and the agriculture interest of downstream countries are main reasons behind reinforced collaboration, regional integration and even political tensions in the region. 
On its turn, to mitigate water-energy-food nexus conflicts in Central Asia, the following recommendations are provided by [2]:

i. As planned, Rogun can be used for energy purposes, while Nurek considers the irrigation interests of the neighboring countries. With this approach, Tajikistan will fully cover its electricity consumption and irrigation will also be maintained in Uzbekistan and Turkmenistan.

ii. Alternatively, the Soviet-period scenario can be rehabilitated-that is, upstream countries provide required water in summer for irrigation and downstream countries supply natural resources (oil, coal, gas) in return to meet the energy demand of upstream economies during the winter period.

Author Contributions: O.S. developed the paper with the supervision of S.P., I.R., J.K. Contribution by authors: Conceptualization, O.S.; Methodology, I.R.; Software, S.P.; Validation, J.K.; Formal Analysis, I.R.; Investigation, S.P.; Resources, J.K.; Data Curation, O.S.; Writing-Original Draft Preparation, O.S.; Writing-Review \& Editing, I.R.; Visualization, J.K.; Supervision, S.P.; Project Administration, O.S.; Funding Acquisition, S.P. All authors have read and agreed to the published version of the manuscript.

Funding: This research received external funding from Swiss National Science Foundation (Scientific Exchange program, grant number: IZSEZ0_183795) and ETH Zurich (visiting scientist grant). Sincere gratitudes to Christian Brethaut (the University of Geneva) for mentoring, supervising and grand acquisition. APC is funded by ETH Zurich.

Conflicts of Interest: The authors declare no conflict of interest.

\section{References}

1. Hoff, H. Understanding the Nexus. In Background Paper for the Bonn 2011 Conference: The Water, Energy and Food Security, Nexus, Bonn, Germany, 16-18 November 2011; Stockholm Environment Institute (SEI): Stockholm, Sweden, 2011.

2. Jalilov, S.-M.; Keskinen, M.; Varis, O.; Amer, S.; Ward, F.A. Managing the water-energy-food nexus: Gains and losses from new water development in Amu Darya River Basin. J. Hydrol. 2016, 539, 648-661. [CrossRef]

3. Granit, J.; Jägerskog, A.; Lindström, A.; Björklund, G.; Bullock, A.; Löfgren, R.; De Gooijer, G.; Pettigrew, S. Regional Options for Addressing the Water, Energy and Food Nexus in Central Asia and the Aral Sea Basin. Int. J. Water Resour. Dev. 2012, 28, 419-432. [CrossRef]

4. Fumagalli, M. Food security in Central Asia: A priority for Western engagement. Cent. Asia Cauc. Anal. 2008, 10, 12-14.

5. Teasley, R.L.; McKinney, D. Calculating the Benefits of Transboundary River Basin Cooperation: Syr Darya Basin. J. Water Resour. Plan. Manag. 2011, 137, 481-490. [CrossRef]

6. Micklin, P. The Aral Sea Disaster. Annu. Rev. Earth Planet. Sci. 2007, 35, 47-72. [CrossRef]

7. CIA. The World Factbook; Central Intelligence Agency: Washington, DC, USA, 2011. Available online: https: //www.cia.gov/library/publications/the-world-factbook/ (accessed on 20 June 2020).

8. UNECE. Reconciling Resource Uses in Transboundary Basins: Assessment of the Water-Food-Energy-Ecosystems Nexus. 2015. Available online: https://www.unece.org/fileadmin/DAM/env/water/publications/WAT_Nexus/ece_ mp.wat_46_eng.pdf (accessed on 19 June 2020).

9. De Strasser, L.; Lipponen, A.; Howells, M.; Stec, S.; Bréthaut, C. A Methodology to Assess the Water Energy Food Ecosystems Nexus in Transboundary River Basins. Water 2016, 8, 59. [CrossRef]

10. Aquastat. The Aral Sea Basin Transboundary River Basin. 2011. Available online: http://www.fao.org/nr/water/ aquastat/countries_regions/fussr/index5.stm (accessed on 15 January 2019).

11. Jalilov, S.-M.; Amer, S.A.; Ward, F.A. Water, Food, and Energy Security: An Elusive Search for Balance in Central Asia. Water Resour. Manag. 2013, 27, 3959-3979. [CrossRef]

12. Bernauer, T.; Siegfried, T. Climate change and international water conflict in Central Asia. J. Peace Res. 2012, 49, 227-239. [CrossRef]

13. Bréthaut, C.; Gallagher, L.; Dalton, J.; Allouche, J. Power dynamics and integration in the water-energy-food nexus: Learning lessons for transdisciplinary research in Cambodia. Environ. Sci. Policy 2019, 94, $153-162$. [CrossRef] 
14. Stucki, V.; Sojamo, S. Nouns and Numbers of the Water-Energy-Security Nexus in Central Asia. Int. J. Water Resour. Dev. 2012, 28, 399-418. [CrossRef]

15. Jennings, N.R.; Faratin, P.; Lomuscio, A.; Parsons, S.; Wooldridge, M.; Sierra, C. Automated Negotiation: Prospects, Methods and Challenges. Group Decis. Negot. 2001, 10, 199-215. [CrossRef]

16. Jalilov, S.-M.; Amer, S.A.; Ward, F.A. Managing the water-energy-food nexus: Opportunities in Central Asia. J. Hydrol. 2018, 557, 407-425. [CrossRef]

17. Rasul, G. Food, water, and energy security in South Asia: A nexus perspective from the Hindu Kush Himalayan region. Environ. Sci. Policy 2014, 39, 35-48. [CrossRef]

18. Allouche, J.; Middleton, C.; Gyawal, D. Nexus Nirvana or Nexus Nullity? A Dynamic Approach to Security and Sustainability in the Water-Energy-Food Nexus; STEPS Working Paper 63; STEPS Centre: Brighton, UK, 2014.

19. Rasul, G. Managing the food, water, and energy nexus for achieving the Sustainable Development Goals in South Asia. Environ. Dev. 2016, 18, 14-25. [CrossRef]

20. GWSP. Sustainability in the Water-Energy-Food Nexus. In Proceedings of the GWSP International Conference "Sustainability in the Water-Energy-Food Nexus", Bonn, Germany, 19-20 May 2014.

21. Leck, H.; Conway, D.; Bradshaw, M.; Rees, J. Tracing the Water-Energy-Food Nexus: Description, Theory and Practice. Geogr. Compass 2015, 9, 445-460. [CrossRef]

22. Keskinen, M.; Guillaume, J.H.A.; Kattelus, M.; Porkka, M.; Räsänen, T.A.; Varis, O. The Water-Energy-Food Nexus and the Transboundary Context: Insights from Large Asian Rivers. Water 2016, 8, 193. [CrossRef]

23. Guillaume, J.H.A.; Kummu, M.; Eisner, S.; Varis, O. Transferable Principles for Managing the Nexus: Lessons from Historical Global Water Modelling of Central Asia. Water 2015, 7, 4200-4231. [CrossRef]

24. Dukhovny, V.; Sokolov, V. Lessons on Cooperation Building to Manage Water Conflicts in the Aral Sea Basin; UNESCO-IHP: Paris, France, 2003.

25. European Environment Agency. Water Use and Environmental Pressures. 2018. Available online: https://www.eea.europa.eu/themes/water/european-waters/water-use-and-environmental-pressures/wateruse-and-environmental-pressures (accessed on 15 June 2020).

26. CA Water Info. Reservoirs and Flow Regulation. 2011. Available online: http://www.cawater-info.net/amudarya/ reservoir_e.htm (accessed on 15 January 2019).

27. World Bank Open Data. Available online: https://data.worldbank.org/ (accessed on 15 June 2019).

28. World Bank. Irrigation in Central Asia: Social, Economic and Environmental Considerations; World Bank: Washington, DC, USA, 2003.

29. Sokolov, V. Future of irrigation in Central Asia. In What Are the Prospects for the Future; IWMI-FAO Workshop on Trends and Transitions in Asian Irrigation: Bangkok, Thailand, 19-21 January 2009.

30. Orlovsky, N.; Orlovsky, L. Water Resources of Turkmenistan: Use and Conservation. 2002. Available online: http: //citeseerx.ist.psu.edu/viewdoc/download?doi=10.1.1.167.2605\&rep=rep1\&type=pdf (accessed on 1 July 2020).

31. Maas, A.; Issayeva, G.; Rüttinger, L.; Umirbekov, A.; Daussa, R. Climate Change and the Water-Energy-Agriculture Nexus in Central Asia; OSCE Scenario Report: Vienna, Austria, 2011; pp. 7-9.

32. World Bank. Key Issues for Consideration on the Proposed Rogun Hydropower Project. September 2014. Available online: http://www.worldbank.org/content/dam/Worldbank/document/eca/central-asia/ World\%20Bank\%20Note\%20-\%20Key\%20Issues\%20for\%20Consideration\%20on\%20Proposed\%20Rogun \% 20Hydropower\%20Project_eng.pdf (accessed on 25 June 2020).

33. World Bank. Central Asia Regional Electricity Exports Potential Study; World Bank: Washington, DC, USA, 2004.

34. Howells, B.; Rogner, R.H. Water-energy nexus: Assessing integrated systems. Nat. Clim. Chang. 2014, 4, $246-247$. [CrossRef]

35. East West Institute. Triggering Cooperation across the Food-Water-Energy Nexus in Central Asia; East West Institute: New York, NY, USA, 2014; pp. 17-19. Available online: https://www.files.ethz.ch/isn/188103/Food-Water-Energy\% 20Nexus\%20in\%20Central\%20Asia.pdf (accessed on 11 June 2020).

36. Sadoff, C.W.; Grey, D. Beyond the river: The benefits of cooperation on international rivers. Water Policy 2002, 4 , 389-403. [CrossRef]

37. Varis, O. Resources: Curb vast water use in central Asia. Nature 2014, 514, 27-29. [CrossRef] [PubMed] 
38. World Bank. Tajikistan's Winter Energy Crisis: Electricity Supply and Demand Alternatives; The International Bank for Reconstruction and Development/The World Bank: Washington, DC, USA, November 2012. Available online: http://siteresources.worldbank.org/ECAEXT/Resources/TAJ_winter_energy_27112012_Eng.pdf (accessed on 5 June 2020).

39. EPRS. Brief of European Parliamentary Research Service: Water in Central Asia-An Increasingly Scarce Resource. 2018. Available online: http://www.europarl.europa.eu/RegData/etudes/BRIE/2018/625181/EPRS_ BRI(2018)625181_EN.pdf (accessed on 29 May 2020).

40. Libert, B.; Orolbaev, E.; Steklov, Y. Water and energy crisis in Central Asia. China Eurasia Forum Q 2008, 6, 9-20.

41. Rahaman, M.M. Principles of Transboundary Water Resources Management and Water-related Agreements in Central Asia: An Analysis. Int. J. Water Resour. Dev. 2012, 28, 475-491. [CrossRef]

42. Wegerich, K. A critical review of the concept of equity to support water allocation at various scales in the Amu Darya basin. Irrig. Drain. Syst. 2007, 21, 185-195. [CrossRef]

43. Madani, K. Game theory and water resources. J. Hydrol. 2010, 381, 225-238. [CrossRef]

44. Akmuradov, M.; Anstey, M.; Baheer, D.M.; Baliev, B.; Baltes, M.; Beilstein, M.; Berkeliev, T.; Boboev, H.; Bogdetskaya, L.; Bournay, E.; et al. Environment and Security in the Amu Darya Basin; UN Environmental Programme (UNEP): Nairobi, Kenya, 2011. Available online: http://envsec.org/publications/AmuDarya-EN-Web. pdf (accessed on 30 May 2020).

45. Rasul, G.; Sharma, B. The nexus approach to water-energy-food security: An option for adaptation to climate change. Clim. Policy 2015, 16, 682-702. [CrossRef]

46. Spoor, M.; Krutov, A. The "Power of Water" in a divided Central Asia. Perspect. Glob. Dev. Technol. 2003, 2, 594-613.

47. Linn, J.F. Water-Energy Links in Central Asia: A Long-Term Opportunity and Challenge; Brookings Institution: Washington, DC, USA, 2008.

(C) 2020 by the authors. Licensee MDPI, Basel, Switzerland. This article is an open access article distributed under the terms and conditions of the Creative Commons Attribution (CC BY) license (http://creativecommons.org/licenses/by/4.0/). 